
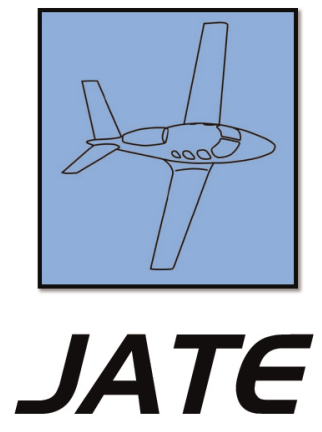

Journal of Aviation Technology and Engineering 1:2 (2012) 63-73

DOI: $10.5703 / 1288284314659$

\title{
Global Outsourcing of Aircraft Maintenance
}

\author{
Michael McFadden \\ NetJets \\ D. Scott Worrells
}

Embry-Riddle Aeronautical University, Worldwide Campus

\begin{abstract}
Before the airlines were deregulated, the majority of air carriers conducted their maintenance in-house. After deregulation, with competitive pressures mounting and airlines failing and starting up seemingly simultaneously, the outsourcing of maintenance became more prevalent. Not restricted to U.S. airlines, outsourcing maintenance has become a global practice. Factors involved in the outsourcing decision range from a startup not having the capital to develop their own in-house maintenance program, to legacy carrier's cost cutting efforts, and all points in between. This paper will address specific aspects of the global outsourcing of aircraft maintenance. For the purposes of this paper, Maintenance, Repair, and Overhaul (MRO) and maintenance are used synonymously.
\end{abstract}

Keywords: Maintenace Repair Overhaul, Outsourcing, Maintenance

\section{Global Outsourcing of Aircraft Maintenance}

For those who study the airline industry, and more specifically, aircraft maintenance, it is a well-known fact that airlines are not in the aircraft maintenance business. However, the importance of quality, compliant, cost effective maintenance cannot be overstated. Estimates for the total cost of aircraft maintenance range from 10\% to $15 \%$ of an air carrier's budget

\footnotetext{
About the Authors

Michael McFadden is a professional pilot flying for the fractional ownership provider Netjets. Mr. McFadden received his graduate degree in Aeronautical Science from Embry-Riddle Aeronautical University in 2011.

D. Scott Worrells is a full time faculty member in Embry-Riddle Aeronautical University's Worldwide Campus. Dr. Worrells holds a doctoral degree in Workforce Education and Development from Southern Illinois University Carbondale, and graduate and undergraduate degrees in Management and Technology-Avionics from Embry-Riddle Aeronautical University.
} 
(Al-Kaabi, Potter, \& Naim, 2007). As recently as 2007, the Federal Aviation Administration (FAA) estimated that "overall, major air carriers outsourced an average of 64 percent of their maintenance expenses compared to 37 percent in 1996" (Department of Transportation, 2008, p. 1). Airlines continually search for ways to reduce this expense, and it is the primary factor in the decision to outsource maintenance.

Economics of scale has an impact on the decision to outsource maintenance. Each individual airline must determine the point at which there is a positive return on the investment in maintenance capability. Large air carriers with hundreds of aircraft can justify the investment for a multi-level maintenance capability. However, an airline with a relatively small fleet may not have the capital, desire, or need to establish a multi-level maintenance program. This is particularly true for startup air carriers and low cost carriers (LCC).

Another factor is the tendency to blend maintenance capability. All air carriers outsource some element of their maintenance requirement. Typically, heavy maintenance, which is labor intensive and requires extraordinary outlay for facilities and equipment, is outsourced. For carriers in the US, $71 \%$ of heavy maintenance is outsourced, with engine maintenance one of the fastest growing segments of the maintenance, repair, and overhaul (MRO) market (Phillips, 2008). On the other end of the maintenance spectrum, ground handling, servicing, and organizational level maintenance is most frequently not outsourced.

Regardless who conducts the maintenance on an airline's aircraft, aircraft maintenance is ultimately the responsibility of the airline (FAA, 2008). Accordingly, the most critical part of the outsourcing process is selecting a reputable MRO provider. While high rates of reliability are always expected, many air carriers are looking for more, such as total support solutions.

\section{Global MRO Growth and Consolidation}

Global MRO revenue in 2002 was between 25 and 30 billion dollars (Czepiel, 2003). Recent economic conditions have reduced short term estimates of MRO demand; however, long term growth is forecast at $4.3 \%$ through 2018 (Phillips, 2009). From 2002 through 2010, average spending for MRO was $\$ 340.2$ billion (see Figure 1). It is estimated to reach $\$ 65$ billion by 2020, doubling the 2003 $\$ 30$ billion estimate by Czepiel.

Projected MRO growth is "particularly strong in India and China, followed by Asia, Europe and North America with less growth in North Africa and the Middle East" (Phillips, 2008, para. 9). The North American MRO market remains largest in dollars spent, at $\$ 15.6$ billion in 2007, "followed by Western Europe ( $\$ 10.4$ billion), Asia-Pacific ( $\$ 5.6$ billion), China ( $\$ 2.3$ billion), the Middle East ( $\$ 2$ billion), South America ( $\$ 2$ billion), Africa ( $\$ 1.5$ billion),

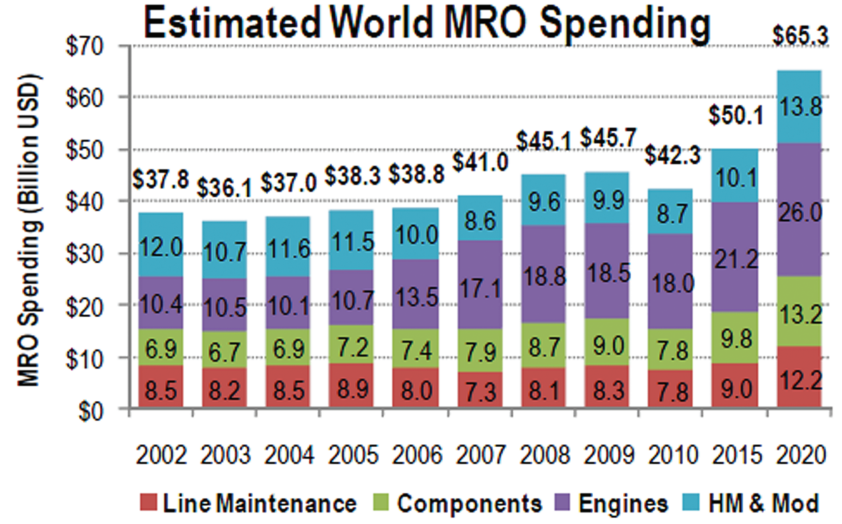

Figure 1. Estimated world MRO spending. Adapted from "Airline maintenance costs executive commentary," 2011, International Air Transport Association, p. 3.

Eastern Europe ( $\$ 1.2$ billion), and India ( $\$ 444$ million)" (Jackman, 2007, para. 18).

The global recession has contributed to consolidation in the MRO industry. Lufthansa Technik (LHT) has started a joint venture with Qantas, opening up LHT Sofia to overhaul short and medium range aircraft and "...several MROs reported forming partnerships with firms in other regions to offer more competitive costs and convenience to customers" (Moody, 2009, para. 16). Aeroman, the largest MRO in Central America, sold $80 \%$ of the company to Air Canada Technical Services in 2006 and now operates under the Aveos brand (Tegtmeir, 2011).

\section{Outsourced Maintenance}

\section{Heavy Maintenance Visits}

Heavy maintenance visits (HMV) will grow from $\$ 9$ billion in 2008 to $\$ 13$ billion in 2017 (Phillips, 2008). Industry experts estimate two-thirds of HMV costs are labor costs (Jackman, 2007). With foreign labor costs less than $50 \%$ of those in the US (see Figure 2), it is easy to see why many air carriers have shifted their HMV to overseas providers (Weaver, 2008), with estimated savings at $\$ 1$ million per aircraft each year (Pandit, 2007).

Delta TechOps Program Manager Beadle concurs, stating: "Labor costs represent approximately $70 \%$ of HMV costs" (M. Beadle, personal communication, February 9, 2011). In 2008, starting pay at Aeroman was approximately $\$ 4,500$ per year with veterans earning approximate $\$ 15,000$. That compares to the U.S. average of $\$ 52,000$ (Smith \& Bachman, 2008). "Delta Airlines sends the majority of wide-body HMV to facilities in the Far East to take advantage of lower labor costs" (M. Beadle, personal communication, February 9, 2011). Narrow body HMV work tends to stay in the Western Hemisphere, with MRO providers in Central America playing a significant role; lower labor costs and shorter ferry flights contribute to cost savings. 


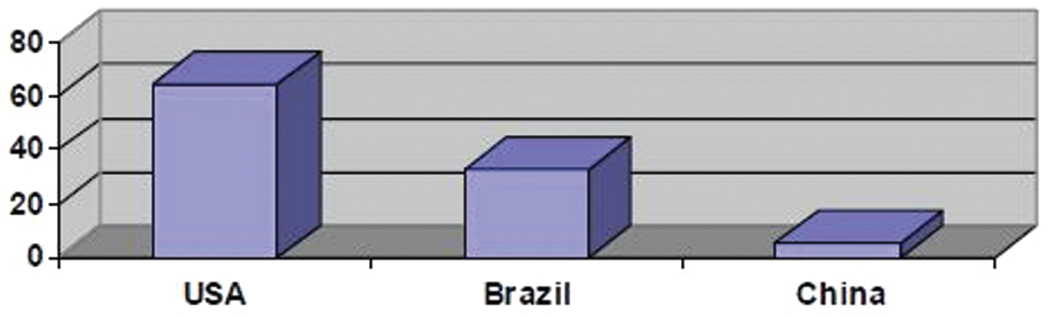

$\square$ Airframe $m$ an hours rate(US\$)

Figure 2. Estimated man hour costs in dollars. Adapted from "Tenets of MRO strategy for airlines," by P. Pandit, 2007, p. 6.

Another factor in the outsourcing equation is the capital investment in facilities, equipment, and associated overhead. The hangar space required to shelter an aircraft that is virtually dissembled is considerable. In addition, the heavy equipment, work stands, test equipment, support equipment, test benches, etc., represent a considerable outlay of capital. And, this equipment needs to be maintained and calibrated on a regular basis, as well. The cost of establishing a heavy maintenance capability can be prohibitive, with breakeven return on investment perhaps 10 to 15 years down the road. Another cost consideration is the maintenance burden, "administrative and overhead costs associated with the maintenance function that cannot be attributed directly to a particular airframe or engine but allocated on a fairly arbitrary basis" (Wensveen, 2007, p. 305).

\section{Power Plant MRO}

Power plant MRO is projected to be the fastest growing segment of MRO at an estimated annual growth rate of 4.6\% (Phillips, 2008). Power plant technology has allowed for greater reliability and on-wing time. While it would be natural to assume that this would translate into reduced costs, that is not necessarily the case; some estimates show power plant maintenance spending increasing "two percent faster than traffic through 2013" (Canaday, 2005, para. 30). The reason for this projected increase is mainly due to the high cost of repair parts. Costs of repair parts from "General Electric (GE), Pratt and Whitney (PW) and CFM International (CFMI) ... [are] increasing at an average of 3.5 to 4.5 percent a year" (Canaday, 2005, para. 27).

\section{Line Maintenance}

Line maintenance is outsourced much less frequently than either heavy maintenance or power plant MRO; however, the outsourcing of line maintenance is primed for growth. AeroStrategy principal Stewart states: "Our analysis estimates that for 2008, about 12 percent of line maintenance is outsourced, and by 2017, that could reach as much as 30 percent" (as cited in Seidenman, 2008, para. 4). Line maintenance occupies a very special place in the operation of an airline due to the direct impact it can have on operational performance, both positive and negative. Delays at the gate can be expensive, with estimates from $\$ 50$ to $\$ 100$ per minute and an outright cancellation up to $\$ 60,000$ (Certified Aviation Services, 2007, para. 17). Before an airline will outsource such a critical function, it needs to be assured that a potential vendor would be able to supply the same level of qualified personnel.

\section{Component Repair and Spare Parts Inventory}

Component repair. The outsourcing of component repair and replacement is also undergoing a significant degree of transformation. As in other areas of aircraft maintenance, established airlines once had their own shops to repair or rebuild components such as landing gear, auxiliary power units, electrical system components, hydraulic-pneumatic system components, and various power plant components. Some even had their own avionics shops for the repair of communication and navigation equipment, flight management systems, and flight instruments.

Airlines look for component support solutions that are flexible, with predictable costs. For example, "Airtran outsources its component support to several large vendors, mostly manufacturers like Honeywell" (Canaday, 2005, para. 69). Borowski, Airtran's vice-president of maintenance and engineering, states: "We pay a rate per flight hour, the invoicing is simple, there is very little administration, and the costs are predictable" (as cited in Canaday, 2005, para. 69).

Spare parts inventory. The cost of inventory runs into millions of dollars and inventory management is labor intensive. While these facts have not changed, the landscape has changed dramatically with airlines reducing the amount of inventory they hold directly, outsourcing it to companies dedicated to inventory management. In 2007, inventories were reduced to $61 \%$ from $75 \%$ of the $\$ 48$ billion spare parts inventory previously stocked and stored (Trebilcock, 2007, para. 2). One airline executive says, "We continue to see upward trending with airlines choosing to get out of the inventory management and repair business" (as cited in Moorman, 2011, para. 3). 
While the benefits of outsourcing component repair and inventory management can be considerable, there are risks. An airline must make sure that it is using a reputable supplier for not only reliability and timely delivery of the required items, but for quality and legitimacy of approved parts, as well.

\section{Production Planning and Control}

Airlines have been reluctant to give up control of production planning and control activities, making them the least outsourced. That may be changing, according to House of TIMCO Aviation Services: "But now that airlines are accustomed to subcontracting to lower labor cost providers, many view outsourcing of the back office as the next cost saving opportunity" (as cited in Seidenman \& Spanovich, 2009, para. 1).

As with the other areas of outsourcing, ultimately a vendor must be able to show that, while they are able to keep costs under control, they can also effectively manage the contracted work. Demeis, president and founder of Continuum Applied Technology, believes that the move to outsource these important functions may be premature:

Frankly, I don't think that any savings involved with outsourcing back office support would be great at this time, because at least a portion of the carrier's quality control department will have to supervise the performance of the third-party company. That means that any savings related by eliminating an internal IT staff position will be greatly diminished. (as cited in Seidenman \& Spanovich, 2009, para. 20)

\section{Regulatory Requirements}

All air carrier maintenance programs have their roots in the initial certification of an aircraft. Design of maintenance programs must be flexible enough to accommodate air carrier specific requirements and must comply with Federal Aviation Regulations (FARs). Most of the world's airlines and manufacturers use the Airline/Manufacturer Maintenance Program Planning Document or Maintenance Steering Group (MSG) in the development of maintenance programs (Air Transport, 2003). The Air Transport Association of America (ATA) administers and maintains this document to provide guidance on the development of maintenance procedures for new aircraft. Specifically, the ATA states:

It is the objective of this document to present a means for developing the scheduled maintenance tasks and intervals which will be acceptable to the regulatory authorities, the operators, and the manufacturers. The scheduled maintenance task and interval details will be developed by coordination with specialists from the operators, manufacturers, and the Regulatory Authority of the country of manufacture. Specifically, this document outlines the general organization and decision processes for determining scheduled maintenance requirements initially projected for the life of the aircraft and/or power plant. (2003, p. 11)

Once these basic regulatory requirements are met, the FAA provides fairly wide latitude on the specific structure of an airline's maintenance operations. According to the FAA:

Establishing appropriate standards and regulatory requirements is a risk management process and the underlying legal structure provides for more than one level of acceptable risk. Air transportation regulations are allinclusive and stand alone, whereas the regulations governing other air commerce do not. Similarly, the scope of responsibility for those in air transportation is very broad and not shared, whereas in other air commerce it is relatively narrow and shared. The regulations in parts 119, 121 and 135 relate directly to air carrier maintenance programs and reflect the highest possible degree of public safety. The regulations in parts $43,65,91$, and 145 do not necessarily reflect the highest possible degree of safety in the public interest. (2008, para. 8)

The FAA sets the tone for Air Carrier Maintenance Programs; it describes in detail how an air carrier may structure its maintenance program. Advisory Circular (AC) 120-16E describes how a maintenance organization can be set up for both a FAR Part 121 or a FAR Part 135 operation.

The foundation and legal basis for airworthiness and maintenance of an air carrier's aircraft is found in FAR Part 121. As stated in FAR Part 121.363:

(a) Each certificate holder is primarily responsible for

(1) The airworthiness of its aircraft, including airframes, aircraft engines, propellers, appliances, and parts thereof; and

(2) The performance of the maintenance, preventive maintenance, and alteration of its aircraft, including airframes, aircraft engines, propellers, appliances, emergency equipment, and parts thereof, in accordance with its manual and the regulations of this chapter.

(b) A certificate holder may make arrangements with another person for the performance of any maintenance, preventive maintenance, or alterations. However, this does not relieve the certificate holder of the responsibility specified in paragraph (a) of this section. (Responsibility for Airworthiness, 1973)

By definition, ACs are not mandatory as issued; AC 120$16 \mathrm{E}$ describes "the scope and content of air carrier aircraft 
maintenance programs" (FAA, 2008, p. i). This AC describes how an air carrier's maintenance program "should reflect three specific program objectives to provide the highest possible level of safety in air transportation" (FAA, 2008, p. 2). These objectives are:

(a) each of your aircraft released to service is airworthy and has been properly maintained for operations in air transportation; (b) maintenance and alterations that you perform, or that other persons perform for you, are performed in accordance with your maintenance manual; and (c) competent personnel with adequate facilities and equipment perform maintenance and alterations on your aircraft. (FAA, 2008, p. 2)

Advisory Circular 120-16E describes the 10 elements required of an air carrier maintenance program. These 10 elements are:

1. Airworthiness responsibility

2. Air carrier maintenance manual

3. Air carrier maintenance organization

4. Accomplishment and approval of maintenance and alterations

5. Maintenance schedule

6. Required Inspection Items

7. Maintenance recordkeeping system

8. Contract maintenance

9. Personnel training

10. Continuing Analysis and Surveillance System (CASS)

Chapter nine of AC 120-16E describes what is expected for contract maintenance. The first paragraph of chapter nine of this AC clearly spells out this responsibility, stating:

Consistent with 121.1 (b), 135.1 (b)(2) and others, when you use a maintenance provider to accomplish all or part of the maintenance activities on your airplane or its component parts, that maintenance provider becomes, in effect, part of your maintenance organization and under your control. (FAA, 2008, p. 33)

\section{The Decision to Outsource}

Prior to deregulation, most aircraft maintenance was conducted in-house (vertically integrated) and, according to Delta TechOps Program Manager Beadle, "years ago no one really paid much attention to the cost of aircraft maintenance. It was all part of doing business" (personal communication, February 9, 2011).

Outsourcing as a business model has become an accepted way for companies to reduce costs and focus on core competencies. Sackett and Sakburanapech state: "Although outsourcing enables companies to focus on

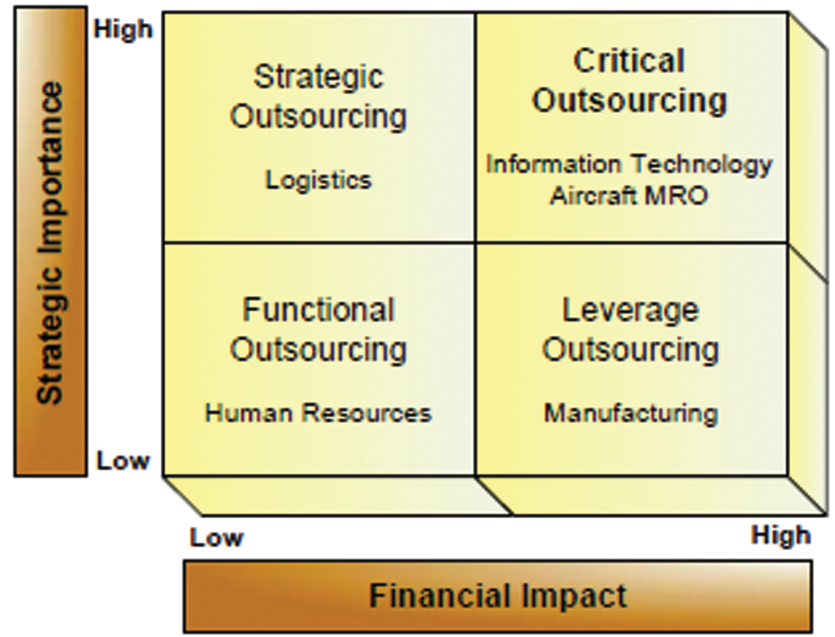

Figure 3. Outsourcing Classifications. Adapted from "Development of a relationship management framework and related performance metrics for outsourced aircraft maintenance," by A. Sakburanapech, 2008, Cranfield University, p. 11

their core competencies and may reduce costs, most enterprises are cautious about outsourcing business critical activities" (2006, p. 1). Critical outsourcing as shown in Figure 3 is "characterized by both high importance and financial impact" (Sakburanapech, 2008, p. 28).

Outsourcing of aircraft maintenance is a business critical activity with regard to strategic importance and finances. What makes outsourcing of aircraft maintenance unique is that lives are potentially at risk if maintenance is not done properly.

Aircraft maintenance is now viewed as a non-core business. However, this widely accepted definition does not apply to all areas of outsourced aircraft maintenance; at least one airline, Jet Blue, considers line maintenance a core competency. Ramage, vice-president of technical services, stated: "Each airline defines what core business is differently. For Jet Blue, line maintenance is a core business; heavy maintenance is not" (as cited in Schifrin, 2007, para. 28).

Rapid emergence of LCCs in the US and abroad has had an impact. These air carriers have decided to outsource maintenance rather than establish maintenance operations from scratch. The maintenance outsourcing trend is well established (see Table 1).

Jet Blue's Director of Maintenance states:

Our business is to fly people safely from one point to the next. Line maintenance is a requirement. You must have that if you want reliability. But when you start talking about MRO, that's a whole different business. It requires a lot of overhead and tooling and we leave that to the experts. They can do it a lot more efficiently than we can. We'll stick to our core business. We believe that will maximize shareholder value. (as cited in "Maintenance Outsourcing: Emerging," 2009, para. 23) 
Table 1

Airline Maintenance Outsourcing (as percentage of total expenses)

\begin{tabular}{llll}
\hline Airline & 2005 & 2006 & 2007 (through Q3) \\
\hline Alaska & $92 \%$ & $80 \%$ & $81 \%$ \\
Hawaiian & $80 \%$ & $86 \%$ & $89 \%$ \\
US Airways $^{\mathrm{a}}$ & $77 \%$ & $81 \%$ & $80 \%$ \\
Northwest $_{\text {America West }}^{\mathrm{b}}$ & $76 \%$ & $83 \%$ & $81 \%$ \\
Continental $_{\text {JetBlue }}$ & $76 \%$ & $91 \%$ & $91 \%$ \\
Southwest & $69 \%$ & $68 \%$ & $70 \%$ \\
AirTran & $68 \%$ & $64 \%$ & $65 \%$ \\
Frontier & $68 \%$ & $81 \%$ & $85 \%$ \\
United & $65 \%$ & $93 \%$ & $94 \%$ \\
Delta & $63 \%$ & $79 \%$ & $80 \%$ \\
American & $48 \%$ & $66 \%$ & $67 \%$ \\
ATA & $46 \%$ & $43 \%$ & $72 \%$ \\
\hline \hline
\end{tabular}

Note. Adapted from "Outsourcing of airline maintenance sours," by W. J. McGee, 2008, Consumer Reports, para. 18.

${ }^{\mathrm{a}}$ Merged with America West, ${ }^{\mathrm{b}}$ Merged with US Airways, ${ }^{\mathrm{c}}$ Ceased operations

Foreign LCCs, one of the fastest growing segments of the worldwide aviation market, feel much the same way. Indicative of this is the view of Jetstar Asia's Head of Engineering, Neo. Neo indicates that he wants an MRO provider with "the capability to provide a full suite of Engineering services, including a proven and strong ability to provide AOG [Aircraft on Ground] recovery from technical breakdowns" (as cited in Moody, 2010, para. 24).

With the trend towards outsourcing, a question arises as to whether an airline should keep the work or send it out.
When evaluating the outsourcing decision, some air carriers use a Make/Buy decision model to help them determine whether or not to outsource. Well established as an accepted course of action in many industries, it provides management with a tool for determining where work should be done. According to Smith, "it is the maximum of every prudent master of the family, never attempt to make at home what it will cost him more to make than to buy" (as cited in Ferreira \& Serra, 2010, para. 1). Is it more cost effective to have someone else do the required work or is it better if it is kept in-house? Transaction Cost Economics is one description of the Make/Buy method. Transaction Cost Economics is "fundamentally concerned with the question of whether it is advantageous, in terms of cost, for transactions to occur within the hierarchy of an organization or externally in the open market" (Rieple, 2008, para. 2). According to Program Manager Beadle, Delta TechOps uses a Make/Buy decision for all of Delta's maintenance work, and while TechOps might be given a preference in getting the bid for some work, if they are not competitive, the work will in fact be outsourced (personal communication, February 9, 2011).

\section{The MRO Model}

Al-Kaabi et al. (2007) describe four levels of MRO: Fully Integrated, Partially Outsourced, Mostly Outsourced, and Wholly Outsourced, as shown in Figure 4. Within these levels, the entire aircraft maintenance spectrum is addressed.

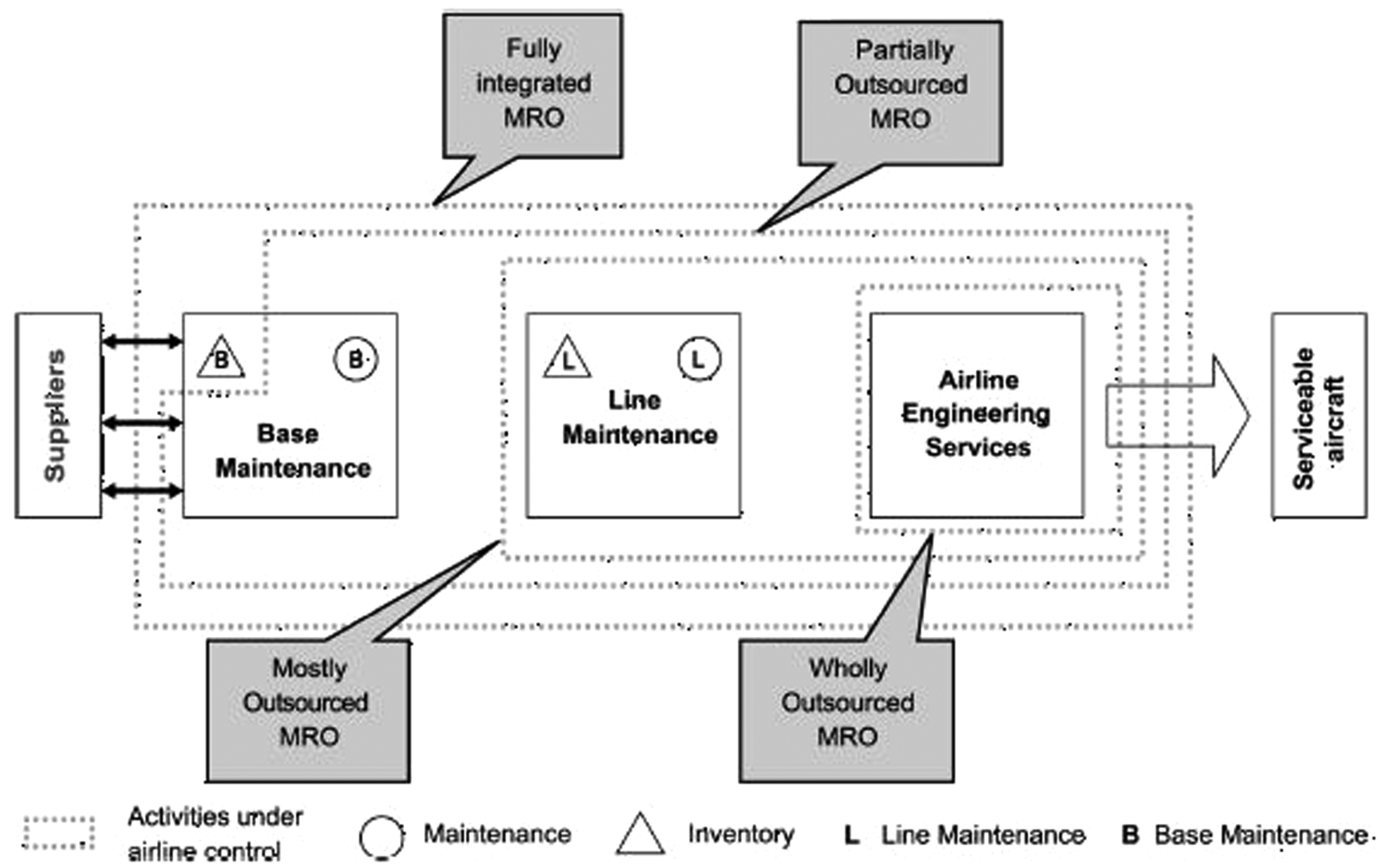

Figure 4. MRO Model Depictions. Adapted from "An outsourcing decision model for airlines' MRO activities," by H. Al-Kaabi et al., 2007, Journal of Quality in Maintenance Engineering, 13(3), p. 220. 


\section{Fully Integrated MRO}

An airline performs all aircraft maintenance activities inhouse. In addition, it may look to sell excess capacity to other airlines.

This practice is well-suited for airlines with large, varied fleets and an extensive route structure (Al-Kaabi et al., 2007).

\section{Partially Outsourced MRO}

An airline meets a large portion of its needs in-house with a minimum of outsourcing. This permits a good deal of flexibility and adaptation to seasonable demands, and is best suited for airlines that have just a few different fleet types.

\section{Mostly Outsourced MRO}

Most maintenance is outsourced while critical needs are kept in-house (Al-Kaabi et al., 2007). "Critical needs" are defined by individual carriers. For example, Jet Blue Airlines defines line maintenance as critical to its operation and keeps most of that activity in-house.

\section{Wholly Outsourced MRO}

All maintenance is outsourced. This model is used by startup airlines that do not have the capital to establish an MRO capability or that choose not to as a part of their business model.

\section{MRO Provider Selection}

Perhaps the most important factor to consider is the selection of the MRO provider. Many variables come into play and each one must be considered carefully. Wyman uses a very thorough six-step process that evaluates all aspects of a provider before making a recommendation to an airline. These six steps are:
1. Define requirements. Develop a detailed description of what is to be expected, including the volume and timing of the work required.

2. Explore and understand the current marketplace. Knowing who is doing quality and reliable work is extremely important.

3. Define outsource strategy and require initial bids for the work. Determine whether or not to bundle/ unbundle services; length of contract; and type of contract.

4. Feedback for bidders. Specific details concerning pricing and suggestions on ancillary services are discussed.

5. Face to face negotiations. Establish terms and conditions. On-site inspection must be a contract provision. Conclude with formal Memorandum of Understanding (MOU).

6. Convert MOU into formal, detailed contract. (as cited in Canaday, 2007, para. 5)

It should be noted here that this last step is recommended by the FAA in AC 120-16E Chapter Nine as an important factor in the outsourcing process. The Federal Aviation Administration states:

When possible, you should have a written contract with anyone performing maintenance work for you on a continuing basis. This will help ensure your responsibilities are addressed. In the case of major operations, such as engine, propeller, or airframe overhaul, the contract should include a specification for the work. You should include or reference that specification in your manual system. (2008, p. 33)

Sakburanapech (2008), describes a process that was developed by Momme and Hvolby that has three phases and six activities, as shown in Figure 5.

The actual selection process varies by airline and is based on needs and priorities set by management. However, regulatory requirements must be addressed to

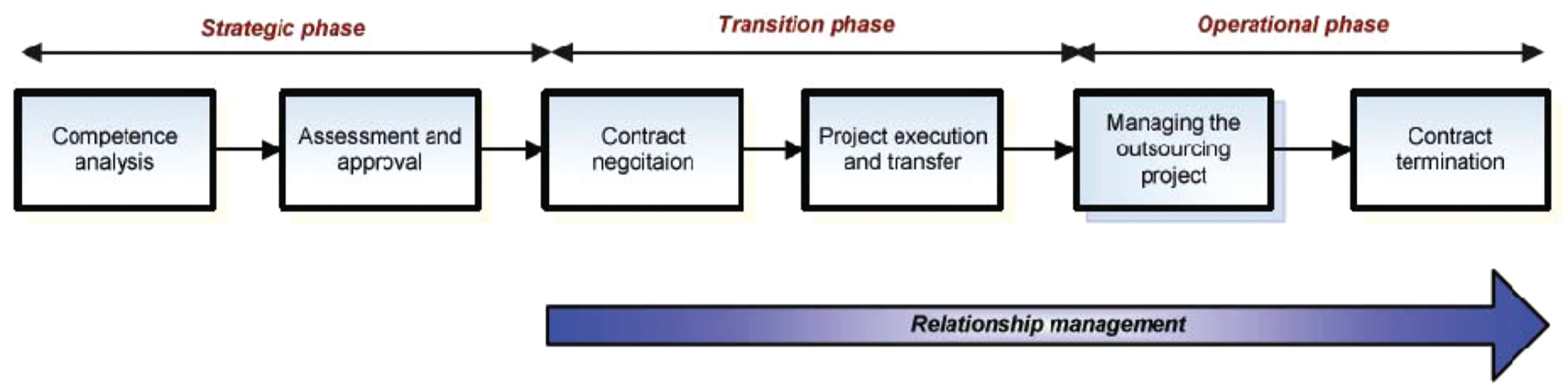

Figure 5. The outsourcing process. Adapted from "Development of a relationship management framework and related performance metrics for outsourced aircraft maintenance," by A. Sakburanapech, 2008, Cranfield University, p. 15. 
the satisfaction of the FAA. For example, Becher, a spokesman for Northwest Airlines stated in 2005:

While costs for outsourced maintenance are lower than for in-house maintenance, quality and safety are not compromised.... Northwest selects them because of their world class management, control systems and technical ability. Outside vendors undergo a rigorous review before being offered a maintenance contract by Northwest. (as cited in "Maintenance Outsourcing," 2009, para. 14)

Jet Blue's vice-president of technical services, Ramage, uses turnaround times and the quality of service as key factors in the selection process. He said "The first thing we look at is the culture of the company. And obviously when I talk about quality, it is what the safety culture is and can they do the job well. Quality, safety and experience is important" (as cited in Arnoult, 2010, para. 7).

\section{The Oversight Process and its Contribution to Safety}

\section{Air Carrier Oversight}

The first line of defense in prevention of errors that may lead to improper maintenance is an air carrier's CASS. Required by FAR Part 121.373, CASS is one of the 10 elements of a maintenance program (Continuing Analysis and Surveillance, 1996):

The high level purpose of a CASS is to reduce or eliminate the likelihood of your aircraft being approved for return for service when it is not airworthy through the continuous, system safety-based, closed loop cycle of surveillance, investigation, data collection, analysis, corrective action, monitoring, and feedback of a CASS. (FAA, 2010, p. 6)
Four basic activities of CASS are: surveillance, analysis, corrective action, and follow up. Encompassed therein are audit processes, data collection processes, Root Cause Analysis (RCA), and performance measurement. This riskbased, closed loop system verifies performance and effectiveness of a maintenance program (see Figure 6) (FAA, 2010).

\section{FAA Oversight}

U.S. repair stations. Problems with FAA oversight of outsourced maintenance and contract repair stations drew attention from Department of Transportation's (DOT's) Office of Inspector General, the public, and the U.S. Congress. The catalyst for this attention was the crash of ValuJet Flight 592 into the Florida Everglades in May, 1996. The ValuJet accident was one of three fatal airline accidents related to contract maintenance (Adams, 2009). The ValuJet accident investigation ultimately laid blame at the feet of the Sabre-Tech (the contract maintenance provider), ValuJet, and the FAA (National Transportation Safety Board, 1997).

International repair stations. The U.S. and select foreign countries recognize each other's aviation safety standards and programs through Bilateral Aviation Safety Agreements (BASA):

The purposes of this Agreement are to: (a) enable reciprocal acceptance of findings of compliance and approvals issued by the Technical Agents and Aviation Authorities; (b) promote a high degree of safety in air transport; and (c) ensure continuation of high level regulatory cooperation and harmonization between US and EC. The scope of cooperation under this Agreement is: (a) airworthiness approvals and monitoring of civil aeronautical products; (b) environmental testing and approvals of civil aeronautical products; and (c)

\begin{tabular}{|c|c|}
\hline $\begin{array}{c}\text { Verify Performance of Maintenance } \\
\text { Program } \\
\end{array}$ & $\begin{array}{c}\text { Verify Effectiveness of Maintenance } \\
\text { Program } \\
\end{array}$ \\
\hline $\begin{array}{l}\text { 1a. Surveillance: Audit process. } \\
\text { - Create an audit plan based on risk } \\
\text { assessment. } \\
\text { - Perform work-in-progress audits. } \\
\text { - Perform transaction audits. } \\
\text { - Perform systems audits. } \\
\text { - Identify hazards. }\end{array}$ & $\begin{array}{l}\text { 1b. Surveillance: Data collection process. } \\
\text { - Select data sets. } \\
\text { - Collect operational data. } \\
\text { - Collect failure data. } \\
\text { - Identify trends, anomalies, and potential } \\
\text { hazards. }\end{array}$ \\
\hline $\begin{array}{l}\text { 2a. Analysis: Iden } \\
\text { accomplish risk an }\end{array}$ & $\begin{array}{l}\text { 2b. Analysis: Identify hazards, investigate } \\
\text { adverse indicators, and accomplish risk } \\
\text { analysis and assessment. }\end{array}$ \\
\hline \multicolumn{2}{|c|}{$\begin{array}{l}\text { 3. Corrective Action: Accomplish Root Cause Analysis (RCA); develop, implement, } \\
\text { and monitor a corrective action plan, as appropriate. }\end{array}$} \\
\hline \multicolumn{2}{|c|}{$\begin{array}{l}\text { 4. Followup (Performance Measurement): Verify the corrective action is effective, } \\
\text { and initiate risk-based followup surveillance planning, as appropriate. }\end{array}$} \\
\hline
\end{tabular}

Figure 6. Four Basic CASS Activities. Adapted from "Developing and implementing an air carrier continuing analysis and surveillance system," 2010, FAA AC 120-79A p. 15. 


\begin{tabular}{|l|l|l|}
\hline Requirement & Certificated Repair Station & $\begin{array}{l}\text { Non-Certificated } \\
\text { Facility }\end{array}$ \\
\hline FAA Inspections & Annual inspection required & No requirement \\
\hline $\begin{array}{l}\text { Quality Control } \\
\text { System }\end{array}$ & $\begin{array}{l}\text { Must establish and maintain a quality control } \\
\text { system that ensures that repairs performed by } \\
\text { the facility or a subcontractor are in } \\
\text { compliance with regulations }\end{array}$ & No requirement \\
\hline $\begin{array}{l}\text { Reporting Failures, } \\
\text { Malfunctions, and }\end{array}$ & $\begin{array}{l}\text { Must report failures, malfunctions, and } \\
\text { defects to FAA within 96 hours of discovery }\end{array}$ & No requirement \\
\hline Personnel & $\begin{array}{l}\text { Must have designated supervisors, inspectors, } \\
\text { and return-to-service personnel }\end{array}$ & No requirement \\
\hline Training Program & Required starting April 2006 & No requirement \\
\hline Facilities and Housing & $\begin{array}{l}\text { If authorized to perform airframe repairs, } \\
\text { must have facilities large enough to house the } \\
\text { aircraft they are authorized to repair }\end{array}$ & No requirement \\
\hline
\end{tabular}

Figure 7. Differences in Requirements for FAA Certificated Repair Stations and Non-Certificated Facilities. Adapted from "Air carriers' use of noncertificated repair facilities,” 2005, Department of Transportation, p. 12.

approvals and monitoring of maintenance facilities. (Council of the European Union, 2011)

Certified/non-certified repair stations. Certification of Part 145 repair stations is subject to regulatory requirements of the FAA; non-certificated stations are not (see Figure 7).

Air carriers ensure through proper audits and oversight that contracted facilities perform according to approved maintenance programs. According to the DOT: "Noncertificated facilities performing critical maintenance creates a double standard because certificated repair stations are required to have designated supervisors, inspectors, return-to-service personnel, and quality control systems. No such requirements apply to non-certificated facilities" (DOT, 2005, p. 6). A DOT investigation found:

....as many as 1,400 domestic and foreign facilities that could perform the same work (e.g., repairing flight control systems and engine parts) a certificated facility performs but are not inspected like certificated facilities. Of those 1,400 facilities, we identified 104 foreign noncertificated facilities-FAA had never inspected any of them. (2005, p. 6)

\section{Conclusion}

Contract maintenance is as old as the aviation industry itself. Over time, and as the aviation industry has evolved, the airline industry has integrated contract maintenance into a post-deregulation business model that emphasizes its core business, transporting passengers/cargo from point to point, while marginalizing, to the greatest extent possible, the cost of aircraft maintenance. Worldwide MROs have grown, in response to continuous and increasing demand, into a viable segment of the aviation industry. Proliferation of MRO facilities worldwide should continue, although growth has slowed as a result of current economic stagnation, as long as the industry and the regulators meet their responsibility to ensure aircraft are maintained to the high standards required by regulation and good business practice.

\section{References}

Adams, C. (2009, June 1). Maintenance outsourcing safety debate. Aviation Today. Retrieved from http://www.aviationtoday.com/ regions/ca/Maintenance-Outsourcing-Safety-Debate_32488.html

Air Transport Association of America. (2003, March). Operator/ manufacturer scheduled maintenance development. Retrieved from http://www.castc.org.cn/weixiu/file/wxgc8.pdf

Arnoult, S. (2010, October 26). Maintenance special report: the MRO quandary. Airline Business. Retrieved from http://www.flightglobal. com/articles/2010/10/26/348942/maintenance-special-report-the-mroquandary.html

Al-Kaabi, H., Potter, A., \& Naim, M. (2007). An outsourcing decision model for airlines' MRO activities. Journal of Quality in Maintenance Engineering, 13(3), 217-227. Retrieved from www.emeraldinsight. com/1355-2511.htm, doi: 10.1108/13552510710780258

Canaday, H. (2005, October 21). Cost control over time. Overhaul and Maintenance. Retrieved from http://www.aviationweek.com/aw/ generic/story_generic.jsp?channel=om\&id=news/om $1005 \mathrm{cvr} . x \mathrm{ml} \&$ headline $=$ Cost $\% 20$ Control $\% 20$ Over\%20Time

Canaday, H. (2007, October 1). Intelligent outsourcing. Overhaul and Maintenance. Retrieved from http://www.aviationweek.com.ezproxy. libproxy.db.erau.edu/search/articleQuickSearch.do?parameter=display

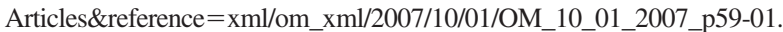
$\mathrm{xml} \&$ pubDate $=$ Oct01,2007\&databaseName $=$ om\&keyword $=$ Intelligent + Outsourcing \&issueDateWT $=10 / 01 / 2007 \&$ publicationName $=$ om $\&$ headline $=$ Intelligent Outsourcing

Certified Aviation Services. (2007, December). Improving the bottom line through outsourced line maintnenance [White Paper]. Retrieved from http:www.certfiedaviation.com

Continuing Analysis and Surveillance, 14 C.F.R. § 121.373 (1996). Retrieved from the FAA Website: http://www.airweb.faa.gov/ 
Regulatory_and_Guidance_Library/rgFAR.nsf/0/05249BA96A808EB D852566EF006C69C9?OpenDocument

Council of the European Union. (2011, March 1). Agreement between the United States of America and the European Community on cooperation in the regulation of civil aviation safety. Retrieved from http://register. consilium.europa.eu/pdf/en/09/st08/st08312.en09.pdf

Czepiel, E. (2003, March). Practices and perspectives in outsourcing aircraft maintenance (DOT/FAA/AR-02/122). Retrieved from the FAA website: https://hfskyway.faa.gov

Department of Transportation, Office of Inspector General. (2005, December 15). Air carriers' use of non-certificated repair facilities (AV-2006-031). Retrieved from the DOT website: http://www.oig.dot. gov/library-item/4044

Department of Transportation, Office of Inspector General. (2008, September 30). Review of air carriers' outsourcing of aircraft maintenance (AV-2008-090). Retrieved from the DOT website: http://www.oig.dot.gov/library-item/4992

Federal Aviation Administration. (2008). Air carrier maintenance programs (Advisory Circular 120-16E). Retrieved from the FAA website: http://www.airweb.faa.gov/Regulatory_and_Guidance_ Library/rgAdvisoryCircular.nsf/0/D505FFC06AECC27E862574C600 5480A2? OpenDocument

Federal Aviation Administration. (2010). Developing and implementing an air carrier continuing analysis and surveillance system (Advisory Circular 120-79A). Retrieved from the FAA website: http://www. airweb.faa.gov/Regulatory_and_Guidance_Library/rgAdvisoryCircular. nsf/0/5BFD9BFF65324C40862577990057AA4F?OpenDocument\& Highlight $=120-79 \mathrm{a}$

Ferreira, M., \& Serra, F. (2010, January-March). Make or buy in a mature industry? Models of client-supplier relationships under TCT and RBV perspective. Brazilian Administration Review 7(1), 22-39. Retrieved from http://www.anpad.org.br/periodicos/arq_pdf/a_1022.pdf, doi: 10. 1590/S1807-76922010000100003

International Air Transport Association. (2011, January). Airline maintenance costs executive commentary. Retrieved from http://www.iata. org/workgroups/Documents/MCTF/AMC_ExecComment_FY09.pdf

Jackman, F. (2007, April 1). MRO market is up and down. Overhaul and Maintenance. Retrieved from http://www.aviationweek.com.ezproxy. libproxy.db.erau.edu/search/articleQuickSearch.do?parameter $=$ display

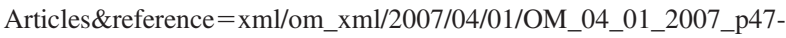
01.xml\&databaseName $=0 m \&$ pubDate $=\mathrm{Apr} \% 2001, \% 202007 \&$ keyword $=$ MRO+Market + is + up + and + down\&issueDateWT $=04 / 01 /$ $2007 \&$ publication Name $=$ om $\&$ headline $=$ MRO $\% 20$ MARKET $\%$ 20IS\%20UP\%20AND\%20DOWN

Maintenance outsourcing: emerging appeal. (2009, October 29). Airline Business. Retrieved from http://www.flightglobal.com/articles/2009/ 10/29/334031/maintenance-outsourcing-emerging-appeal.html

Maintenance outsourcing trends. (2005, April). Aircraft Technology Engineering \& Maintenance. Retrieved from http://relaisill.com/ posttoweberau/servlet/DownloadDocument?2361787.pdf

McGee, W. J. (2008, May 23). Outsourcing of airline maintenance soursConsumer Reports. Retrieved from http://blogs.consumerreports. org/safety/2008/05/airline-safety.html

Moody, E. (2009, June 1). Top 10 airframe MRO providersOverhaul and Maintenance. Retrieved from http://www.aviationweek.com.ezproxy. libproxy.db.erau.edu/search/articleQuickSearch.do?parameter=display

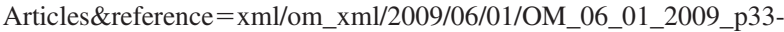
143878.xml\&pubDate $=$ Jun $\% 2001, \% 202009 \&$ databaseName $=$ om\& keyword $=$ Top $+10+$ Airframe + MRO + Providers\&issueDateWT $=06 / 01 /$ $2009 \&$ publicationName $=$ om\&headline $=$ Top $\% 2010 \% 20$ Airframe $\%$ 20MRO\%20Providers\&INTERCEPT_MESSAGES $=$ S_IP_AUTH\& PRIOR_REQUEST_URL $=\% 2$ Fsearch $\% 2$ FarticleQuickSearch.do $\%$ 3Fparameter\%3DdisplayArticles\%26reference\%3Dxml\%2Fom_xml\% 2F2009\%2F06\%2F01\%2FOM_06_01_2009_p33-143878.xml\% 26pubDate\%3DJun $\% 252001 \% 2 \mathrm{C} \% 25202009 \% 26$ databaseName $\%$ 3Dom\%26keyword\%3DTop\%2B 10\%2B Airframe\%2BMRO\%
2 B Providers \% 26issueDateWT\%3D06\%2F01\%2F2009\% 26publicationName\%3Dom\%26headline\%3DTop \%252010\% 2520Airframe\%2520MRO\%2520Providers

Moody, E. (2010, November 1). Southeast Asia special: Dynamic demandsOverhaul and Maintenance. Retrieved from http://www. aviationweek.com/aw/generic/story_generic.jsp?channel $=$ om $\&$ $\mathrm{id}=$ news/om/2010/11/01/OM_11_01_2010_p22-260993.xm1\& headline $=$ null\&next $=10$

Moorman, R. (2011, January 1). ROI for rotables. Overhaul and Maintenance. Retrieved from http://www.aviationweek.com.ezproxy. libproxy.db.erau.edu/search/articleQuickSearch.do?parameter=display Articles\&keyword $=\mathrm{ROI}+$ for + rotables\&reference $=\mathrm{xml} / \mathrm{om} \_\mathrm{xml} / 2011$ / 01/01/OM_01_01_2011_p51-275643.xml\&databaseName $=$ om \& issueDateWT $=01 / 01 / 2011 \&$ publicationName $=$ om $\&$ headline $=$ ROI For Rotables\&pubDate $=$ Jan 01, 2011

National Transportation Safety Board. (1997, August 19). In-flight fire and impact with terrain ValuJet flt 592 (NTSB/AAR-97/06). Retrieved from the NTSB website http://www.ntsb.gov/publictn/1997/aar9706. pdf

Pandit, P. (2007, December). Tenets of MRO strategy for airlines. Retrieved from http://www.infosys.com/offerings/industries/airlines/ white-papers/Documents/tenets-MRO-strategy.pdf

Phillips, E. (2008, January 28). Decade of growth ahead for MROAviation Week and Space Technology. Retrieved from http://www.aviationweek. com.ezproxy.libproxy.db.erau.edu/search/articleQuickSearch.do? parameter $=$ displayArticles $\&$ reference $=x m 1 /$ awst_xml/2008/01/28/ AW_01_28_2008_p65-15687.xml\&databaseName =awst\& pubDate $=\mathrm{Jan} \% 2028, \% 202008 \&$ keyword $=$ Decade + of + growth + ahead + for+MRO\&issueDateWT $=01 / 28 / 2008 \&$ publicationName $=$ awst $\&$ headline $=$ Decade $\% 20$ of $\% 20$ Growth $\% 20$ Ahead $\% 20$ for $\% 20 \mathrm{MRO}$

Phillips, E. (2009, January 26). Market outlook for MRO sector. Aviation Week and Space Technology. Retrieved from http://www.aviationweek. com.ezproxy.libproxy.db.erau.edu/search/articleQuickSearch.do? parameter $=$ displayArticles\&reference $=$ xml/awst_xml/2009/01/26/ AW_01_26_2009_p57-93380.xml\&pubDate $=$ Jan\%2026,\%202009\& databaseName $=$ awst $\&$ keyword $=$ Market+outlook+for + MRO+sector $\&$ issueDateWT $=01 / 26 / 2009 \&$ publicationName $=$ awst \&headline $=$ Market $\% 20$ Outlook\%20for\%20MRO\%20Sector

Responsibility for Airworthiness, 14 C.F.R. § 121.363 (1973). Retrieved from the FAA website: http://www.airweb.faa.gov/Regulatory_and_ Guidance_Library/rgFAR.nsf/0/3AA283C5FA474201852566EF006C 62D3? OpenDocument\&Highlight $=121.363$

Rieple, A. (2008). Outsourcing for competitive advantage: an examination of seven legacy airlines. Journal of Air Transport Management, 14, 280-285. doi:10.1016/j.jairtraman.2008.06.002

Sackett, P., \& Sakburanapech, A. (2006). Criterion for success in critical outsourcing (IAMOT 1682-1544). Retrieved from http://www.iamot. org/conference/index.php/ocs/10/paper/view/1682/772

Sakburanapech, A. (2008, August). Development of a relationship management framework and related performance metrics for outsourced aircraft maintenance. Retrieved from the Cranfield University website http://dspace.lib.cranfield.ac.uk/handle/1826/4091

Schifrin, C. (2007, March 1). Leveraging line maintenance. Overhaul and Maintnenance. Retrieved from http://www.aviationweek.com.ezproxy. libproxy.db.erau.edu/search/articleAdvanceSearch.do?parameter $=$ displayArticles\&reference $=\mathrm{xml} / \mathrm{om} \_\mathrm{xml} / 2007 / 03 / 01 / 0 M \_03 \_01$ _ 2007_p28-01.xml\&databaseName $=$ om\&pubDate $=$ Mar $\% 2001, \%$ $202007 \&$ keyword $=\% 201$ ine $\% 20$ maintenance $\% 20$ outsourcing \& issueDateWT $=03 / 01 / 2007$ \&publicationName $=$ om\&headline $=$ Leveraging \%20Line\%20MaintenanceSeidenman, P. (2008, October 1). Line maintenance outsourcing. Overhaul and Maintenance. Retrieved from http:// www.aviationweek.com.ezproxy.libproxy.db.erau.edu/search/articleQuick Search.do?parameter $=$ displayArticles\&reference $=\mathrm{xml} / \mathrm{om} \_\mathrm{xml} / 2008 / 10 /$ 01/OM_10_01_2008_p39-81712.xml\&databaseName $=$ om\&pubDate $=$ Oct 01, 2008\&keyword = outsourcing+line+maintenance\&issueDateWT $=$ 
$10 / 01 / 2008 \&$ publicationName $=$ om $\&$ headline $=$ Line Maintenance Outsourcing

Seidenman, P., \& Spanovich, D. J. (2009, August 1). What's next for the office? Overhaul and Maintenance. Retrieved from http://www. aviationweek.com.ezproxy.libproxy.db.erau.edu/publication/om/ loggedin/AvnowStoryDisplay.do?fromChannel $=\mathrm{om} \& \mathrm{pubKey}=\mathrm{om} \&$ channel $=$ om\&issueDate $=2009-08-01 \&$ story $=x m 1 / o m \_x m 1 / 2009 / 08 /$ 01/OM_08_01_2009_p44-151365.xml\&headline $=$ Whats+Next+For+ The+Office $\% 3 \mathrm{~F}$

Smith, G., \& Bachman, J. (2008, April 10). The offshoring of airplane care. Bloomberg Businessweek. Retrieved from http://www. businessweek.com/bwdaily/dnflash/content/apr2008/db2008049_ 205948.htm

Tegtmeir, L. (2011, April 1). Central America, an emerging marketOverhaul and Maintenance. Retrieved from http://www. aviationweek.com.ezproxy.libproxy.db.erau.edu/publication/om/ loggedin/AvnowStoryDisplay.do?fromChannel $=\mathrm{om} \&$ pubKey $=\mathrm{om} \&$ channel $=$ om \&issueDate $=2011-0401 \&$ story $=$ xml/om_xml/2011/04/
01/OM 04_01_2011_p33-297952.xml\&headline $=$ Central+America\% $3 \mathrm{~A}++$ An+Emerging+Market

Trebilcock, B. (2007, December 1). Links in the chain: changing dynamics in the MRO supply chain. Overhaul and Maintenance. Retrieved from http://www.aviationweek.com.ezproxy.libproxy.db.erau.edu/search/ articleQuickSearch.do?parameter $=$ displayArticles\&reference $=\mathrm{xml} /$ om_xml/2007/12/01/OM_12_01_2007_p51-02.xml\&databaseName= om\&pubDate $=$ Dec01,$\quad 2007 \&$ keyword $=$ Links + in + the + chain $\% 3 \mathrm{~A}+$ Changing+dynamics\&issueDateWT $=12 / 01 / 2007 \&$ publicationName $=$ om\&headline $=$ Changing Dynamics In The MRO Supply Chain

Weaver, J. (2008, August). Outsourcing aircraft maintenance designed around safety, diversification and performance (SAE 2008-01-2266). Retrieved from http://www.sae.org/search?searchfield=2008-012266\&typ $=$ paper

Wensveen, J. G. (2007). Airline pricing, demand, and output determination. In, Air transportation: a management perspective (6th ed., pp. 283-318). Burlington, VT: Ashgate. 